\title{
NETWORK ACTION FOR THE CARE OF ADOLESCENT VICTIMS OF VIOLENCE: CHALLENGES AND POSSIBILITIES ${ }^{1}$
}

\author{
Cláudia Fabiane Gomes Gonçalves², Lygia Maria Pereira da Silva3, Ana Carolina Rodarti Pitangui, Cintia \\ Cibele da Silva ${ }^{5}$, Marcela Virgínia de Santana ${ }^{6}$
}

\footnotetext{
${ }^{1}$ Article extracted from the thesis - Network care of adolescents suffering violence: the perspective of health care professionals, presented to the Programa de Pós-Graduação de Hebiatria, Universidade de Pernambuco (UPE), in 2014.

${ }^{2}$ M.Sc. in Adolescent Medicine. Recife, Pernambuco, Brazil. E-mail: claudia@pesqueira.ifpe.edu.br

${ }^{3}$ Ph.D. in Nursing. Professor at the Faculdade de Enfermagem Nossa Senhora das Graças and at the Programa de Pós-Graduação em Hebiatria, UPE. Recife, Pernambuco, Brazil. E-mail: lygia.silva@upe.br

${ }^{4}$ Ph.D. in Sciences. Professor at the Curso de Fisioterapia and at the Programa de Pós-Graduação em Hebiatria, UPE. Recife, Pernambuco, Brazil. E-mail: carolina.pitangui@upe.br

${ }^{5}$ Nursing student at the Faculdade de Enfermagem Nossa Senhora das Graças, UPE. Recife, Pernambuco, Brazil. E-mail: cintiabele@ hotmail.com

${ }^{6}$ Nursing student at the Faculdade de Enfermagem Nossa Senhora das Graças, UPE. Recife, Pernambuco, Brazil. E-mail: celasantana@ hotmail.com
}

\begin{abstract}
The aim of the present study was to investigate the perception of health care service managers about the network action for the care of adolescent victims of violence. A qualitative, exploratory, descriptive study conducted from May to July of 2013. The subjects were 15 managers of a hospital that is a referral center for cases of violence in the Brazilian State of Pernambuco. Data were collected through semi-structured interviews and explored using content analysis. The results indicate that social work plays an aggregating and interconnecting role as required by the network action. The health care network is appreciated, but regarded as providing insufficient actions, with lack of standardization of care and service flow. We conclude that the subjects show a positive perception of the role of the studied service, but they point out a lack of specific technical standards in the health care sector aimed at high quality care for adolescents.
\end{abstract}

DESCRIPTORS: Adolescent. Violence. Social networking. Health services. Protection.

\section{ATUAÇÃO EM REDE NO ATENDIMENTO AO ADOLESCENTE VÍTIMA DE VIOLÊNCIA: DESAFIOS E POSSIBILIDADES}

RESUMO: O objetivo deste estudo foi investigar a percepção de gerentes de serviços de saúde sobre a atuação em rede para o atendimento aos adolescentes vítimas de violência. Estudo descritivo, exploratório, com abordagem qualitativa, realizado de maio a julho de 2013. Os sujeitos foram 15 gerentes de serviços de um hospital de referência para atendimento aos casos de violência, no Estado de Pernambuco, Brasil. Os dados foram coletados por meio de entrevistas semiestruturadas, explorados com base na Análise de Conteúdo. Os resultados indicaram que o serviço social exerce um papel agregador e articulador requerido pela atuação em rede. A rede de atendimento é valorizada, mas considerada insuficiente em ações, com falta de normatização da assistência e do fluxo de atendimento. Conclui-se que os sujeitos demonstram percepção positiva do papel do serviço estudado, mas apontam carência de normas técnicas específicas no setor da saúde voltadas a uma atenção de qualidade para adolescentes.

DESCRITORES: Adolescente. Violência. Rede social. Serviços de saúde. Proteção.

\section{ACTUACIÓN EN RED EN EL ATENDIMIENTO AL ADOLECENTE VÍCTIMA DE VIOLENCIA: DESAFÍOS Y POSIBILIDADES ${ }^{1}$}

RESUMEN: Objetiva investigar la percepción de los jefes de servicios de salud respecto a la actuación en red para el atendimiento a adolecentes víctimas de violencia. Estudio descriptivo, exploratorio, con enfoque cualitativo. El objeto del estudio fueron 15 jefes de servicios de salud en Pernambuco, Brasil. Los datos fueron recopilados por intermedio de entrevistas no estructuradas, explorados con base en el Análisis de Contenido. Los resultados indican que el servicio social ejerce una función de agregar y articular requerida por el servicio en red. La red de atendimiento es valorada, sin embargo es considerada insuficiente respecto a acciones, con falta de regularización del socorro y del atendimiento. Se concluye que el objeto en estudio demuestra percepción positiva de la función del servicio estudiado, aunque apunta carencia de normas técnicas específicas en el área de la salud dirigidas a un atendimiento de calidad para adolecentes.

DESCRIPTORES: Adolecente. Violencia. Red social. Servicios de salud. Protección. 


\section{INTRODUCTION}

Adolescence consists of a biological process and organic experiences, with accelerated cognitive development and structuring of the personality. According to the World Health Organization (WHO), this period covers the second decade of life, ages ten to 19 years, a definition also adopted in Brazil by the Ministry of Health (MH). ${ }^{1}$ However, the Statute of the Child and Adolescent (SCA) defines adolescence as the age range between 12 and 17 years, 11 months and 29 days. $^{2}$

In Brazil, although there are laws that protect and ensure the rights to life and health of this population, many of these rights continue to be violated. ${ }^{3}$ Violence against adolescents is a phenomenon that occurs in all settings and is unveiled in different ways, established by numerous factors that affect the social reality, constituting a serious threat to life. ${ }^{4}$

International studies indicate that over one in eight children and adolescents between two and 17 years old have experienced some form of violence in the United States. ${ }^{2}$ In Nicaragua these percentages are $26.0 \%$ for girls and $20.0 \%$ for boys, whereas another study in a public school in Chile shows that $80.4 \%$ of parents admitted using corporal punishment as education. ${ }^{5}$ Brazilian studies show that all age groups are victimized; in the age group of ten to 14, physical violence is the most frequently reported. It should be noted that this type of violence is not prevalent in public; most occurs in the child's home, and a great proportion is performed by the parents. ${ }^{3}$ Violence and accidents together are the second general cause of death in Brazil. Violence is the leading cause of all deaths between ages five to 19 years. ${ }^{6}$ According to the Notifiable Diseases Information System (Sinan), 1,375 cases of violence with adolescents aged 14 to 19 years were registered in Brazilian State of Pernambuco in $2011 .{ }^{7}$

Care of adolescents in situations of violence is guaranteed in several documents, laws, plans and policies, based on the Theory of Integrative Protection. ${ }^{7}$ This theory arose from popular movements that began to demand comprehensive, universal and equal care, and it was established by the United Nations' (UN) International Convention on the Rights of the Child of in 1989, supported by the Universal Declaration of the Rights of the Child of 1959, also contemplated by the Constitution of the Federative Republic of Brazil, then by the
SCA, consolidating it within a true paradigm on the understanding of childhood and adolescence in Brazil. ${ }^{8}$ The SCA is considered a breakthrough in guaranteeing the rights of Brazilian children and adolescents. This document addresses the prevention and restraint of several forms of violence against children and youth. ${ }^{2}$ One study demonstrated that the SCA, based on the Doctrine of Integrative Protection, determined that any violation or omission of their fundamental rights is an transgression by adult caregivers (or the State, society and institutions) and they must be blamed and held and responsible. ${ }^{9}$

From the perspective of the Doctrine of Integrative Protection, confronting violence against adolescents demands the articulation of a network that meets the needs of the problem, addressing its complexity, through public plans and policies aimed toward interdisciplinary and intersectorial actions. ${ }^{10}$ A network of support services or social support network can be represented as "the set of systems of significant people that make up the received and perceived links of relationship of the individual". ${ }^{11: 247}$ The networks represent opportunities to offer solidarity and support during episodes in which an individual or family goes through difficult experiences. ${ }^{11}$

Several institutions make up the network of protection for victims and their families, such as Law Councils, Child Protection Services (CPS), prosecutors, and childhood and adolescence court, as well as other institutions that provide services, such as: schools, health care units, welcoming units, as well as other social support networks. ${ }^{12}$

Among the many services that care for violence cases, health care units are an important gateway for users who are victims. ${ }^{13-14}$ In order to qualify the care offered by the health sector, the National Policy of Reduction of Morbidity and Mortality from Accidents and Violence (NPRMAV) states that health care professionals should be trained and services structured for the actions of victim protection and prevention of violent events. ${ }^{14}$

This policy assumes the coordination of the health sector with other sectors, according to Article 86 of the SCA: "the politics of care of the rights of the child and adolescent shall be conducted through a coordinated set of governmental and non-governmental actions of the Union, the states, the Federal District and municipalities". ${ }^{2}$ The ar- 
ticulation indicated in the SCA characterizes the action of the network, with a view toward meeting the rights of children and adolescents.

The network action requires an interdisciplinary approach and it is believed that the effectiveness of actions depends on the integration of professionals and services. This perspective represents a paradigm shift because there is a prevalence of a disciplinary view by the professionals and services, which generates fragmented performance with overlaps or gaps in the actions performed. ${ }^{15}$

Given the above, this study is justified by the need to reveal the care network of adolescent victims of violence in a referral center in the state of Pernambuco, both within the structure, and the specific qualification of the professionals within the network, and seeks to answer the following questions: 1) How do the service managers involved in care of adolescent victims of violence understand network actions? 2) How do network actions occur to provide care for adolescents in situations of violence in a health referral service?

Thus, this study aimed to investigate the perception of health care service managers about the action of the network for the care of adolescents victims of violence.

\section{METHODS}

This was a qualitative, exploratory and descriptive study, ${ }^{16}$ seeking to contribute to planning of strategies that enable the extension of protection to adolescents.

The research setting was the Hospital da Restauração (HR), a health unit that is a reference for the care of child and adolescent victims of violence, which admits patients from all the state of Pernambuco and other states of the Northeast region of Brazil. ${ }^{17}$ The Internal Network for Care to Children and Adolescents Victims of Violence (NCCAVV), created in 1990 , is located within the HR to offer care to victims through an interdisciplinary team with internal and external articulations for integrated actions. ${ }^{17}$

The study subjects were managers of the hospital services, defined according to the criteria of convenience or acessibility. ${ }^{18}$ The aim of the study was explained, and the interview was scheduled at a time and place that respected the availability and privacy of respondents. All managers partici- pated and signed the consent form. The inclusion criterion was working as the service manager; the exclusion criteria were working in the service for less than one year, and being on vacation or leave during data collection.

The participants were 15 health care professionals aged 30 to 58 years, 12 female and three male. Regarding their education, all had a university degree, with a minimum and maximum time working in the service of three and 38 years, respectively. Twelve had significant experience with violence, having worked ten to 24 years.

The data were collected between May and July of 2013, through individual semi-structured interviews. ${ }^{19}$ For recording of the interview, as agreed with subjects, a tape recorder was used in order to ensure reliability. These interviews were transcribed verbatim, with the most intense and frequent content highlighted. Each interviewed subject was identified with the letter $S$, and numbered 1 to 15 (S1, S2, S3, etc.).

The interview script was based on guiding questions that sought to identify the perceptions of professionals about actions in the network for the care of adolescent victims of violence. 1) What do you understand to be the network action? 2) In the institution in which you work, are there actions that characterize network action? Explain. 3) What should the actions be that would be characterized as networking to fight violence against adolescents?

The interview analysis was based on content analysis technique, considering thematic modality. ${ }^{20}$ There was a pre-analysis phase, during which reading was performed to establish contact with the discursive completeness of the material and, from there, information relevant to the theme was identified. The categorization of themes and subthemes was then performed.

As for the ethical aspects, the project was submitted to the Ethics Committee of the Universidade de Pernambuco, and was approved under CAAE n. 06601012.8.0000.5207.

\section{RESULTS AND DISCUSSION}

Two categories emerged from the analysis of the interviews: "The health care service as a reference" with the subcategories "the service is a reference", "the service acts in a network", "social work as a bridge to resolution"; and "Challenges 
for network actions", with the subcategories "lack of care standardization" and "investment in human resources". Once these empirical categories were defined, the statements were separated, and they were grouped according to their content and meaning, which guided the discussions.

\section{The health care service as a reference}

The health care sector is the space in which most cases of violence converge, and this quest puts pressure on emergency services, specialized care, physical and psychological rehabilitation, and social care. ${ }^{13-21}$ This fact points to the need for the government to consider this as a public health problem.

\section{The service is a reference}

In general, the participants recognize the importance of the hospital for the care of victims of violence, as denoted by the statements below:

[...] it's a service that has a lot of credibility with the whole society. This issue of reference is a huge burden, because all those who seek the service want a solution (S5).

The subject's statement shows that the service is a reference center for the care of cases of violence throughout the state, and the actions to cope with the problem in the health care service take place in a larger context, the health care policies. ${ }^{13,21-22}$

The position of the studied service as a reference center results in expectations and demands that its actions are resolute.

[...] They demand resolution from the service, what was done? Why did you fail to do it? It's as if it were natural, at the same time it's good because this demand won't let things be left behind (S5).

Because the health care sector is a gateway for caring for the cases of violence, the scientific literature states that the sector is a privileged locus for identifying these situations. ${ }^{13,23}$

\section{The service functions within a network}

Much has been discussed about network care for the protection of adolescent victims of violence. In this context, the $\mathrm{MH}$ emphasizes the importance of organizing care networks on health in the Unified Health System (SUS), defining them as integrated structures for the provision of health actions and services, institutionalized by public policies from collectively planned work, and deepening of the interdependent relationships among the actors. ${ }^{24}$ Building networks requires that decisions are made horizontally, under the principles of equality, democracy, cooperation and solidarity. ${ }^{25-26}$

The respondents demonstrated an understanding that the network of protection for adolescent victims of violence requires an intersectoral and interdisciplinary intervention, extrapolating the limits of the health care sector.

[...] We seek this networking on a daily basis through contacts with other agencies out there (S5); [...] Working in the hospital and taking it to a network that works out there [...] (S3).

Thus, it can be noted in the statements of the subjects that there is teamwork and articulation between the different professional categories in the handling of cases. Networking is a strategy that strengthens advocacy, accountability and support for adolescents suffering violence. ${ }^{8}$

In this regard, the literature shows that actors within the networks of care for the country's violent situations also recognize that inter-institutional actions, rather than being a principle, is an absolute necessity, given the complexity of the problem. ${ }^{27}$

The subjects' statements are in line with the findings of several studies that claim that the provision of effective care that addresses individual, institutional and social aspects, will occur above all by establishing referral systems between the health care sector and other sectors that also care for adolescents. ${ }^{6-8}$ However, this care network, although it is highly valued, is considered insufficient, especially in its actions towards adolescents.

\section{Social service as a bridge for resolution}

The context of violence against adolescents requires the work of an interdisciplinary team. The organization of the service studied denotes the leading position at work in the social service network, establishing a link between the health care for the adolescent victim of violence and other instances of protection for this vulnerable group.

According to the statements, social service is the bridge for the resolution of cases of violence.

[...] Social service plays this role of bridging the gap, the communication between the various agencies 
for external interventions [...] (S15); [...] Social service takes on the case to solve it. It may take a while, but they demand and solve (S9).

Social service plays an aggregation and articulation role among the services for integrated actions aimed at strengthening relationships among the members of the network. According to subjects' statements, social workers work directly in the identification of suspected or confirmed cases of violence, and can also be called by other professionals involved in care.

[...] When we, here in the institution, need to refer to other agencies we ask social services who bridges the gap, and they see about it, make contact, take all measures (S4); [...] In fact, when there are external linkages, the ones who takes this on are social services, they see about everything. We communicate, they do a survey of case data, and take appropriate action (S12).

The social service sector of the studied institution has a structured program focused on the theme, aiming primarily to defend the rights of child victims of violence. ${ }^{17}$

In this context, managers recognize the particular professional importance of social work in networking. In addition, they believe that the service has been fulfilling its role within its means, notwithstanding the operational barriers.

\section{Challenges for network actions}

Confronting violence against adolescents requires the articulation of a network that meets the needs of approaching the problem in its complexity. ${ }^{11}$ However, one notices that network actions have difficulties, such as differences in the goals of institutions, articulation deficiencies, lack of care standardization, isolation of services, lack of flow and professional qualifications. ${ }^{27}$

\section{Lack of care standardization}

The implementation of an institutional protocol for the care for adolescent victims of violence can be a strategy for identifying situations of violence, avoiding customized actions without scientific grounding. ${ }^{3}$ In the construction of these instruments, an extended look during care is required, based on recognizing the person under care as a subject with rights. ${ }^{28}$ The health work process should converge with what is recommended in the SUS guidelines, and the SCA with regard to integrality of care. ${ }^{3}$
[...] Protocols for cases of violence, because, this way, all employees would follow the same routine, regardless of the professional category, of course making the necessary referrals (S1); [...] Lack of protocol for these cases, with details on how to proceed, where to refer (S12).

Respondents reveal concern about the lack of standardization, which results in difficulties in care. A care protocol designed for network action should include the flowcharts that are internal and external to the service, seeking articulation among the existing policies. ${ }^{8}$ Knowing these needs, the subjects point to the lack of a planned flow as an obstacle.

[...] The existing bureaucracy impairs information a lot. We should be more practical, have a flow, standards, protocols, which would improve the actions a lot, because I think agility in the cases can be a determining factor (S10); [...] A flowchart is lacking in order to get to work evenly, not only in the hospital, but in the whole state [...] (S9).

The lack of definition of a care flow was one of the points cited by all respondents, revealing that the flow exists occasionally but not systematically. These reports are in line with studies that indicate problems related to the lack of knowledge or interruption of the flow, causing some professionals to act in an isolated, disarticulated way, often using personal contacts to monitor the cases.,22

Given this complexity, the statement on the lack of counter-referral shows an important weakness for the network actions.

[...] The counter-referral, which doesn't exist... I think it doesn't cost anything sending a report even by e-mail. This would even encourage the professionals who are working. There's no interdisciplinarity (S5); [...] The counter-referral is a failure, the response is delayed or doesn't get there, and we get the feeling of working without interruption (S13).

In intersectoral actions to fight violence, it is critical that there is inclusion of the health care sectors, education, legal, security, social welfare, among others, in order to enable decision-making and the implementation of decentralized actions. This work requires interdisciplinary intervention, due to the characteristic of the phenomenon and the damage to victims. ${ }^{3}$

The referral and counter-referral reported by the subjects refers to the CPS, which is in line with the study developed in five Brazilian capitals, which found that in almost all health care services, referrals of child victims of violence go to the CPS, to the Station of Protection of Police of Children 
and Adolescents (SPCA), or to care programs and social service. ${ }^{29}$

Intersectorality and difficulties for its implementation are constantly highlighted in the subjects' statements. The respondents identify, in intersectorality, a new possibility for comprehensive care for adolescents, but also a challenge that is impaired by the operationalization of the actions. It is considered important to monitor and know what happened to the adolescents, when the subjects complain of not knowing the outcome of the cases.

[...] What I said is that we don't have this counterreferral, because if we professionals knew the outcome of cases, it would be a stimulus (S4).

Therefore, respondents show in their statements the obstacles encountered to ensure intersectoral bias among public policies for fighting violence, which highlights the intersectoral approach, which, according to the subjects, covers communication and continuity of actions: [...] the lack of communication among the sectors that make up the network addressing violence, so that protective measures are ensured and monitored for compliance (S15). [...] Who are our referral centers? If you ask this of health care professionals, there are few who know it. I know we have the CPS, the Station [...] (S10); [...] The publishing of the hospital profiles with each type of care, because it would facilitate a lot the people cared for, from the countryside to the capital (S5).

Studies have shown the need for investment in the dialogue of managers, professionals, articulation among units and evaluation of actions in order to ensure quality care for victims of violence. ${ }^{9,29}$ The lack of communication among institutions about the cases of violence, especially those of advocacy and care, weakens and pulverizes the existing institutions. ${ }^{26}$

Communication in this process is of critical importance for the network of protection to really be established and, therefore, for its actions to be effective. Communication (common+action) refers to the idea of planned actions implemented in conjunction with one another. It means sharing information and responsibilities, focusing mainly on the protection of adolescents. ${ }^{30}$

\section{Investment in human resources}

Continuing with the purpose of organizing the care network, training was another object of questioning, as shown in the following statements:
[...] with teenagers 15 years old or older there is a much greater neglect, but with the child and the younger adolescents care is very qualified (S1); [...] I think we could strengthen ourselves with trainings and knowledge of the law itself [...] (S13); [...] Hence the need for training of professionals working with these children and adolescents, including seeing about the social issues so there is a real understanding of the cases and how to conduct a proper intervention (S15).

The statement from S1 signals the difficulty faced by adolescents in the hospital emergency room. Even in emergency situations, this care still often happens in an unqualified way, because adolescence is a stage of life when priorities and inclusions are not recognized. However, the SCA guarantees the right to health care, through the SUS health services network in the various levels of complexity. ${ }^{31}$

Thus, it is essential that these spaces in which there is recognition of the needs of these users by care/investigation/reporting can be implemented in order to effectively fulfill this demand with strategies to cope with violence, which will mobilize several levels of support that make up the network. These actions can identify their specific needs, considering the adolescent as an active subject in the process of care for his health. ${ }^{30}$

There is the need to train professionals working with this theme so as to enable them to achieve a real understanding of the cases and to conduct appropriate intervention, given that health care professionals are often the first to be sought. ${ }^{22}$ Several studies point to the existence of that lack of training, given the problem, identified as a challenge to be overcome, in order to allow them to offer to the victims and their families the necessary care that is compatible with the complexity of the cases. ${ }^{23,29}$

The training of personnel has been considered a priority and is done using multidisciplinary approaches, involving workers in the health service network, seeking definitive solutions, not punctual ones, regardless of their area of expertise. University education, in their perception, is not enough for the acquisition of skills and sensitivity to the conduct of cases. Several studies corroborate the subjects' statements, which reveal gaps in vocational training, making them feel unprepared to deal with the problem..$^{8,23}$

In practice, this care must go far beyond basic university education, because intellectual 
training alone is not enough to confront the issue of violence. ${ }^{22}$ Professionals must be prepared to deal with suspected or confirmed cases of violence in order to identify, report, communicate and refer, proceed to welcoming, care, treatment and necessary referral for interdisciplinary and intersectorial work..$^{9,22}$

\section{FINAL CONSIDERATIONS}

The results of this study made it possible to analyze the perception of service managers about the network action on the care of adolescent victims of violence, from a referral health facility in Pernambuco. Based on these results, it can be seen that the subjects showed a positive perception of the network action in the studied service. However, respondents indicated lack of specific technical standards, protocols and flow charts for the care of adolescents experiencing violence.

Given the complexity and the impact of violence on the health of adolescents, this article aimed to contribute to the enhancement of the involvement of managers in approach and attention, based on the paradigm of integrative protection, with the promotion of management practices being critical. The need to include this theme in the education of professionals from different areas was evidenced, in order to equip them for their work with adolescents in situations of violence. Similarly, the involvement of health care services, professional agencies and higher education institutions proved indispensable in the training of professionals for a committed and competent performance.

It is noticed that, despite the existence of specific legislation in Brazil, it is still necessary to move forward and overcome the lack of recognition of adolescents as subjects with rights who have encountered a biopsychosocial developmental condition.

Faced with the many repercussions of violence in the lives of adolescents, it is essential to promote the commitment of the actors concerned with the theme, in order to set and implement policies that confront violence. There is a need, therefore, to consolidate network actions that integrate various professionals and services.

The results of this study are expected to contribute to the construction of knowledge, and favor reflection on the subject. The theme is understood to have many challenges to be overcome; further studies are necessary to address the problem in its complexity, covering a multidisciplinary view and intersectoral actions for the policy of coping with mild violence to the effective protection of adolescents.

\section{REFERENCES}

1. Krug EG, Dahlberg LL, Mercy JA, Zwi AB, Lozano R, editores. Relatório mundial sobre violência e saúde [online]. Genebra (CH): World Health Organization; 2002 [acesso 2013 Jun 19]. Disponível em: http:// www.opas.org.br/cedoc/hpp/ml03/0329.pdf

2. Brasil. Lei n. 8.069, de 13 de julho de 1990: dispõe sobre Estatuto da Criança e do Adolescente [online]. Brasília (DF): Senado; 2008 [acesso 2013 Feb 18]. Disponível em: http:/ / www.planalto.gov.br/ ccivil_03/leis/18069.htm

3. Cocco M, Silva EB, Hahn AC, Poll AS. Violência contra crianças e adolescentes: estratégias de cuidado adotadas por profissionais de saúde. Ciênc Cuid Saúde 2010; 9(2):292-300.

4. Gomes AVO, Gomes AVO, Antunes JCP, Silva LR, Nascimento, MAL, Silva MDBS. A criança vítima de violência doméstica: limites e desafios para a prática de enfermagem. Rev Pesqui Cuid Fundam (Online) [online]. 2010 [acesso 2013 Abr 11]; 2(2):902-12. Disponível em: http:/ /www.seer.unirio.br/index. php/cuidadofundamental/index.

5. World Health Oganization. World Report on violence and Health [online]. Geneva $(\mathrm{CH})$ : World Health Organization 2002 [acesso 2004 ago 13]. Disponível em: http:/ / www5.who.int/violence_ injury_prevention/download.cfm?id=0000000582

6. Souza MKB, Santana JSS. Atenção ao adolescente vítima de violência: participação de gestores municipais de saúde. Ciênc Saúde Coletiva [online] 2009 [acesso 2013 ago 25]; 14(2):547-55. Disponível em: http:/ / www.scielo.br/scielo.php?pid=S1413$81232009000200023 \&$ script=sci_arttext

7. Ministério da Saúde (BR). Banco de dados do Sistema Único de Saúde [online]. Brasília (DF); 2012 [acesso 2012 out 23]. Disponível em: http:/ / www. datasus.gov.br

8. Silva LMP, Ferriani MGC, Silva MAI. O poder judiciário como última instância de proteção às crianças e aos adolescentes: ações intersetoriais, investimento em recursos humanos e estruturação dos serviços. Rev Latino-Am Enferm [online] 2012 [acesso 2013 mar 10]; 20(3):444-52. Disponível em: http://www.scielo.br/pdf/rlae/v20n3/ pt_a04v20n3.pdf

9. Franzin LCS, Olandovski MO, Vettorazzi MT, Werneck RI, Moysés SJ, Kumas SZ, Moysés ST. Child and adolescent abuse and neglect in the city of Curitiba, Brazil. Child Abuse Negl [online] 2014 [acesso 2015 jun. 24]; 38(10):1706-14. Disponível em:: 
http://www.sciencedirect.com/science/article/ pii/S0145213414000428

10. Costa MCO, Brigas M. Mecanismos pessoais e coletivos de proteção e promoção da qualidade de vida para a infância e adolescência. Ciênc Saúde Coletiva 2007; 12(5):1101-9.

11. Rosa EM, Lira MOSC. Intrafamiliar violence against children and adolescents: support and overcoming network. J Hum Growth Dev. 2012; 22(2):246-52.

12. Silva LMP. A prevenção da violência sexual intrafamiliar contra crianças e adolescentes, sob a ótica dos membros do Poder Judiciário [tese]. São Paulo: Universidade de São Paulo; 2010.

13. Holanda VR, Holanda ER, Souza MA. O enfrentamento da violência na estratégia saúde da família: uma proposta de intervenção. Revista RENE 2013; 14(1):209-17.

14. Ministério da Saúde (BR). Portaria n. 737, de 16 de maio de 2001: institui a Política Nacional de redução da morbimortalidade por acidentes e violências. Brasília (DF): MS; 2001.

15. Ude W. Enfrentamento da violência sexual infantojuvenil e construção de redes sociais: produção de indicadores e possibilidades de intervenção. In: Cunha EP, Silva EM, Giovanetti MAGC organizador. Enfrentamento à violência sexual infanto-juvenil: expansão do PAIR em Minas Gerais. Belo Horizonte (BH): UFMG; 2008. p. 30-61.

16. Guerra, IC. Pesquisa qualitativa e análise de conteúdo sentidos e formas de uso. São João do Estoril (PT): Princípia; 2006.

17. Melo LAC, Souza LF, Alves RMPS. Avaliação do "Programa de Atuação do Serviço Social do Hospital da Restauração no Atendimento as Crianças e Adolescentes Vítimas de Violência". In: Anais do I Seminário Internacional de Modelos e Experiências de Avaliação de Políticas, Programas e Projetos [online]; 2010. Recife (PE): UFPE; 2010 [acesso 2013 Fev 18]. p. 223-30. Disponível em: http://www. arcus-ufpe.com/files/semeap10/semeap1024.pdf

18. Gil AC. Métodos e técnicas de pesquisa social. São Paulo (SP): Atlas; 2006.

19. Minayo MCS. O desafio do conhecimento: pesquisa qualitativa em saúde. $10^{a}$ ed. São Paulo: Hucitec; 2007.

20. Bardin L. Análise de conteúdo. Lisboa (PT): Edições 70; 2002.
21. Silva LMP, Ferriani MGC, Silva MAI. Atuação da enfermagem frente à violência sexual contra crianças e adolescentes. Rev Bras Enferm 2011; 64(5):919-24.

22. Aragão AS, Ferriani MGC, Vendruscollo TS, Souza $\mathrm{SL}$, Gomes R. Abordagem dos casos de violência à criança pela enfermagem, na atenção básica. Rev Latino-Am Enferm [online] 2013 [acesso 2013 Jul 20]; 21(esp.):172-9. Disponível em: http://www.scielo. br/pdf/rlae/v21nspe/pt_22.pdf.

23. Budó MLD, Schimith MD, Silva DC, Silva SO. Percepções sobre a violência no cenário de uma unidade de saúde da família. Cogitare Enferm. 2012; 17(1):21-8.

24. Ministério da Saúde (BR). Linha de cuidado para a atenção integral a saúde de crianças, adolescentes e suas famílias em situação de violências: orientações para gestores e profissionais de saúde. Brasília (DF): MS; 2010.

25. Silva SF. Organização de redes regionalizadas e integradas de atenção à saúde: desafios do sistema único de saúde (Brasil). Cad Saúde Coletiva 2011;16(6):2753-62.

26. Secretaria de Estado de Saúde do Distrito Federal (BR). Manual para atendimento às vítimas de violência na Rede de Saúde Pública do Distrito Federal. $2^{\text {a }}$ ed. Brasília (DF): Secretaria de Estado de Saúde; 2009.

27. Pelisoli C, Pires JPM, Almeida ME. Violência sexual contra crianças e adolescentes: dados de um serviço de referência. Temas Psicol. 2010;18(1):85-97.

28. Deslandes SF, Souza ER, Minayo MCS, Costa CRBSF, Krempe M, Cavalcanti ML et al. Caracterização diagnóstica dos serviços que atendem vítimas de acidentes e violências em 5 capitais brasileiras. Ciênc Saúde Coletiva. 2007; 11(Sup):1279-90.

29. Ministério da Saúde (BR). Diretrizes Nacionais para a Atenção Integral à Saúde de adolescentes e jovens na promoção, proteção e recuperação da saúde. Brasília (DF): MS, 2010.

30. Faraj SP, Siqueira AC. O atendimento e a rede de proteção da criança e do adolescente vítima de violência sexual na perspectiva dos profissionais do Creas. Barbarói 2012; 37(2):67-87.

31. Queiroz MVO, Ribeiro EMV, Pennafort VPS. Assistência ao adolescente em um serviço terciário: acesso, acolhimento e satisfação na produção do cuidado. Texto Contexto Enferm. 2010 Abr-Jun; 19(2):291-9. 